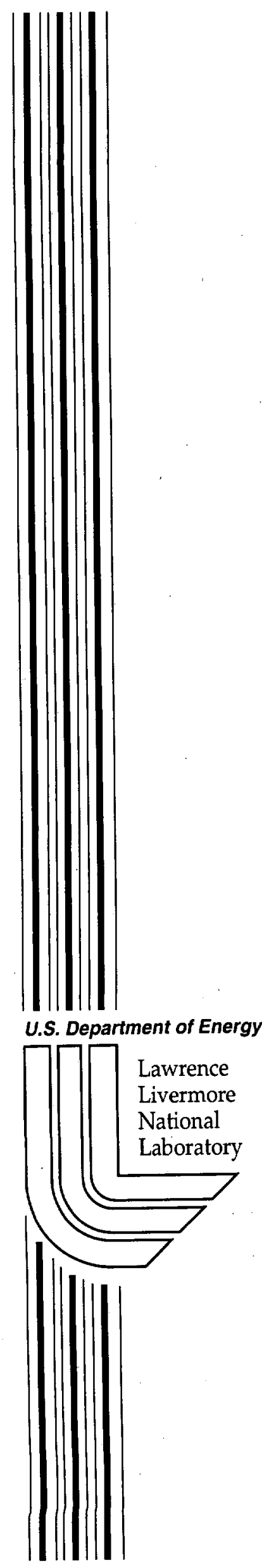

UCRL-ID-146917

\title{
Development of Tritium AMS for Biomedical Sciences Research
}

K.H. Dingley, M.L. Chiarappa-Zucca

January 1, 2002 


\section{DISCLAIMER}

This document was prepared as an account of work sponsored by an agency of the United States Government. Neither the United States Government nor the University of California nor any of their employees, makes any warranty, express or implied, or assumes any legal liability or responsibility for the accuracy, completeness, or usefulness of any information, apparatus, product, or process disclosed, or represents that its use would not infringe privately owned rights. Reference herein to any specific commercial product, process, or service by trade name, trademark, manufacturer, or otherwise, does not necessarily constitute or imply its endorsement, recommendation, or favoring by the United States Government or the University of California. The views and opinions of authors expressed herein do not necessarily state or reflect those of the United States Government or the University of California, and shall not be used for advertising or product endorsement purposes.

This work was performed under the auspices of the U. S. Department of Energy by the University of California, Lawrence Livermore National Laboratory under Contract No. W-7405-Eng-48.

This report has been reproduced directly from the best available copy.

Available electronically at http://www.doe.gov/bridge

Available for a processing fee to U.S. Department of Energy and its contractors in paper from

U.S. Department of Energy Office of Scientific and Technical Information P.O. Box 62

Oak Ridge, TN 37831-0062

Telephone: (865) 576-8401

Facsimile: (865) 576-5728

E-mail: reports@adonis.osti.gov

Available for the sale to the public from

U.S. Department of Commerce

National Technical Information Service

5285 Port Royal Road

Springfield, VA 22161

Telephone: (800) 553-6847

Facsimile: (703) 605-6900

E-mail: orders@ntis.fedworld.gov

Online ordering: http://www.ntis.gov/ordering.htm

\section{OR}

Lawrence Livermore National Laboratory

Technical Information Department's Digital Library http://www.llnl.gov/tid/Library.html 


\title{
Development of Tritium AMS for Biomedical Sciences Research
}

\author{
Final Report \\ Exploratory Research in the Institutes Proposal
}

Karen H. Dingley, Molecular Toxicology Group, BBRP

Marina L. Chiarappa-Zucca, Health and Ecological Assessment, E\&ES

\begin{abstract}
Tritium $\left({ }^{3} \mathrm{H}\right)$ is a radioisotope that is extensively utilized in biological research. Normally in the biological sciences, ${ }^{3} \mathrm{H}$ is quantified by liquid scintillation counting. For the most sensitive measurements, liquid scintillation counting requires large samples and counting times of several hours. In contrast, provisional studies at LLNL's Center for Accelerator Mass Spectrometry have demonstrated that Accelerator Mass Spectrometry (AMS) can be used to quantify ${ }^{3} \mathrm{H}$ in milligram-sized biological samples with a 100 to 1000 -fold improvement in detection limits when compared to scintillation counting. This increased sensitivity is expected to have great impact in the biological research community. However, before ${ }^{3} \mathrm{H}$ AMS can be used routinely and successfully, two areas of concern needed to be addressed: 1) sample preparation methods needed to be refined and standardized, and 2) smaller and simpler AMS instrumentation needed to be developed.

To address these concerns, the specific aims of this project were to: 1) characterize a small dedicated ${ }^{3} \mathrm{H}$ AMS spectrometer 2) develop routine and robust biological sample preparation methods, and 3) with the aid of our external collaborations, demonstrate the application of ${ }^{3} \mathrm{H}$ AMS in the biomedical sciences.

Towards these goals, the ${ }^{3} \mathrm{H}$ AMS instrument was installed and optimized to enhance performance. The sample preparation methodology was established for standard materials (water and tributyrin) and biological samples. A number of biological and environmental studies which require ${ }^{3} \mathrm{H}$ AMS were undertaken with university collaborators and our optimized analysis methods were employed to measure samples from these projects.
\end{abstract}

\section{Purpose and Approach}

Our initial motivation to develop ${ }^{3} \mathrm{H}$ AMS came from our results in applying the ${ }^{14} \mathrm{C}$ AMS technique to biomedical and environmental tracer research. LLNL pioneered the use of ${ }^{14} \mathrm{C}$ AMS in the biological sciences ${ }^{[1]}$ and has shown that the application of ${ }^{14} \mathrm{C}$ AMS can provide an increase of $10^{3}$ in detection sensitivity over decay counting, allowing a $10^{3}$ reduction in sample size or a $10^{3}$ decrease in delivered radio-isotope dose.

Our initial bio ${ }^{14} \mathrm{C}$ AMS efforts created great interest in the international biological research community and consequently sparked interest in the development of ${ }^{3} \mathrm{H}$ AMS. A bio- ${ }^{3} \mathrm{H}$ AMS capability is expected to have great impact in biological research for two reasons. First, ${ }^{3} \mathrm{H}$ is the most widely used radioisotope in biomedical research, with the number of commercially available ${ }^{3} \mathrm{H}$-labeled compounds far exceeding the number of commercially available ${ }^{14} \mathrm{C}$-labeled compounds. Therefore, ${ }^{-3} \mathrm{H}$ AMS measurement capability will facilitate experiments using compounds that are simply unavailable in ${ }^{14} \mathrm{C}$-labeled form, or are extremely expensive. Second, a ${ }^{3} \mathrm{H}$ AMS capability, when used in conjunction with ${ }^{14} \mathrm{C}$ AMS, will allow. unique low-level double-labeling experiments to be performed. Consequently, the development of a ${ }^{3} \mathrm{H}$ AMS capability will significantly increase the application of AMS in the biomedical sciences research community.

Prior to this proposal, our preliminary work demonstrated that biomedical ${ }^{3} \mathrm{H}$ AMS provided a 100 to 1000 -fold improvement in detection sensitivity for assaying samples as small as $0.5 \mathrm{mg}$ for ${ }^{3} \mathrm{H}$ content when compared to conventional decay counting techniques. ${ }^{[2]}$ In addition, we demonstrated that ${ }^{3} \mathrm{H}$ AMS could be used in conjunction with ${ }^{14} \mathrm{C}$ AMS for 
investigating the distribution and metabolism of very low levels of two independent compounds in biological systems. ${ }^{[3]}$. However, although a preliminary ${ }^{3} \mathrm{H}$ AMS sample preparation method had been developed for the measurement of ${ }^{3} \mathrm{H}$ in water standards and solid biological samples, (and these methods were adequate for demonstration purposes), these methods lacked the robustness and reproducibility needed for routine ${ }^{3} \mathrm{H}$ AMS analyses. Therefore, before ${ }^{3} \mathrm{H}$ AMS can be used routinely and successfully in biological research, it is necessary to optimize the current sample preparation methodology and adapt it for the analysis of a diversity of sample forms and sizes likely to be generated in a biological study.

In order for the ${ }^{3} \mathrm{H}$ AMS technique to be widely accepted, it became clear that instrumentation which would fall within the financial, resource, and space limitations of a typical university or regional research center must be developed. There are few institutions in the world that can afford to build and maintain a facility as large as the LLNL AMS facility. Consequently, LLNL collaborated with AccSys Technology, Inc. of Pleasanton, California in a Phase I and Phase II National Institutes of Health/National Cancer Institute Small Business Innovative Research (SBIR) project to build and characterize a compact biomedical ${ }^{3} \mathrm{H}$ AMS system. The system (covered under LLNL/U.S. Patent Number $5,189,302$ ) is based on a LLNL customized ion source and an AccSys Radio Frequency Quadrupole (RFQ) linac (covered under U.S. Patent Number 5,315,120). AccSys. Technology transferred the prototype compact biomedical ${ }^{3} \mathrm{H}$ AMS system to LLNL in exchange for LLNL demonstrating the viability of the system as a biomedical analytical tool.

\section{Technical Accomplishments}

\section{Instrument Characterization and Optimization}

This aim was completed in FY00. The ion source control parameters of the instrument were optimized for maximum ${ }^{3} \mathrm{H}$ count rate while maintaining steady ${ }^{1} \mathrm{H}$ current. The accelerator cavity field was characterized to determine the setting that maximizes beam transmittance. The foil used in front of the ${ }^{3} \mathrm{H}$ detector to exclude other ions was designed using stopping power calculations. The foil maximized ${ }^{3} \mathrm{H}$ energy while stopping both ${ }^{1} \mathrm{H}$ and ${ }^{2} \mathrm{H}$ ions within the foil. The calculations were verified with measurements of ${ }^{2} \mathrm{H}$ and ${ }^{3} \mathrm{H}$ in the detector for different foil materials and thickness.

Once the instrument was initially optimized and the basics of the sample preparation of water standards established, a standard curve was measured for ${ }^{3} \mathrm{H}:{ }^{1} \mathrm{H}$ concentrations ranging from $10^{-10}$ to $10^{-13}$, with a detection limit of $10^{-14}$. These results were presented at the $8^{\mathrm{ch}}$ International Conference on Accelerator Mass Spectrometry in Vienna, Austria and accepted for publication: Roberts, M.L., R.W. Hamm, K.H. Dingley, M.L. Chiarappa, and A.H. Love (2000) A compact tritium AMS system. Nuclear Instruments and Methods in Physics Research B. 172: 262-267 (see attached, UCRL-JC-135902, refereed publication).

\section{Sample Chemistry and Sample Processing Methods}

A method was developed for the preparation of samples for analysis of ${ }^{3} \mathrm{H}$ content by AMS. Organic samples are converted to a solid, titanium hydride, which can be analyzed by AMS, in a two-step process in which the sample is first oxidized to carbon dioxide and water. The water is then transferred via a heated manifold to a second reaction tube, reduced to hydrogen gas using zinc and adsorbed onto titanium powder. The ${ }^{3} \mathrm{H} /$ hydrogen $\left({ }^{1} \mathrm{H}\right)$ ratio of the titanium hydride is established by AMS, which is then used to calculate the amount of ${ }^{3} \mathrm{H}$ in the original sample. Water, organic standards and biological samples containing ${ }^{3} \mathrm{H}$ were utilized to develop and validate the method. ${ }^{3} \mathrm{H} /{ }^{1} \mathrm{H}$ ratios were quantified in samples that contained ${ }^{3} \mathrm{H}$ concentrations spanning six orders of magnitude, with a detection limit of 0.04 $\mathrm{dpm} / \mathrm{mg}$ of material. Smaller samples can be analyzed following addition of $2 \mathrm{mg}$ of a hydrogen carrier. Preparation of organic standards containing both ${ }^{14} \mathrm{C}$ and ${ }^{3} \mathrm{H}$ demonstrated 
that this methodology can also quantify both of these isotopes in small organic samples. This work is being prepared for submission to Analytical Chemistry.

\section{Applications of ${ }^{3} \mathrm{H}$ AMS}

In collaboration with Dr. M. Hellerstein (UCB), a novel method for the measurement of cell turnover using ${ }^{3} \mathrm{H}$ AMS has been developed. This method should provide significant improvements over current methods which either: use toxic chemicals, high levels of radioactivity or lack the sensitivity necessary for measuring low rates of cell turnover. Importantly, this method will enable us to examine the effects of cancer-causing chemicals on cells following very low-dose exposures. In the procedure, animals are fed ${ }^{3} \mathrm{H}_{2} \mathrm{O}$ in their drinking water. As the cells divide, the ${ }^{3} \mathrm{H}$ becomes incorporated into the newly synthesized DNA, which is then analyzed by ${ }^{3} \mathrm{H}$ AMS. A proof-of-principle experiment was performed using this novel methodology and the turnover times established for the liver, colon epithelium, thymus and bone marrow.

We actively collaborated with Dr. J. Hunt (UCB) and his graduate student Adam Love to analyze ${ }^{3} \mathrm{H}$ in tree samples. Public health concerns over the release of ${ }^{3} \mathrm{H}$ near residential or agricultural areas have generated the need for better techniques to evaluate exposure levels. The ${ }^{3} \mathrm{H}$ concentration in the cellulose of trees has been shown to accurately reflect the ${ }^{3} \mathrm{H}$ concentration in the source water and may contain the only historical record of ${ }^{3} \mathrm{H}$ exposure. Tritium AMS lowers the sample size requirement and decrease sample analysis time compared to liquid scintillation counting. Thus, ${ }^{3} \mathrm{H}$ can be measured in tree rings at environmental levels without destroying the tree. Adam Love, a graduate student, spent a significant amount of time working on this project at LLNL and has submitted a manuscript for publication (see attached, UCRL-JC-146720, refereed publication).

\section{Summary}

AMS can be used to quantify ${ }^{3} \mathrm{H}$ in small biological samples at very low (attomole) levels. This technique is enabling LLNL biologists and our University collaborators to conduct studies of national interest that would otherwise be impossible and has strengthened LLNL's position as a center for university-based biological research. Importantly, LLNL is the only institution in the world with a bio- ${ }^{3} \mathrm{H}$ AMS capability.

The ${ }^{3} \mathrm{H}$ AMS instrument has been characterized. The sample preparation methodology has been established for standard materials (water and tributyrin) and biological samples. A number of collaborative studies which require ${ }^{3} \mathrm{H}$ AMS have been initiated at UC and LLNL.

Due to the broad range of biological applications of ${ }^{3} \mathrm{H}$ AMS, it has been included in a recently funded NIH Research Resource grant.

\section{References}

[1] J.S. Vogel and K.W. Turteltaub, 'Bimolecular Tracing through Accelerator Mass Spectrometry', Trends in Analytical Chemistry, 11 (1992) 142-149.

[2] M.L. Roberts, C. Velsko, and K.W. Turteltaub, Tritium AMS for Biomedical Applications', Nuclear Instruments and Methods in Physics Research, B92 (1994) 459-462.

[3] K. Dingley, M.L. Roberts, C. Velsko, and K.W. Turteltaub, 'Attomole detection of ${ }^{3} \mathrm{H}$ in biological Samples Using Accelerator Mass Spectrometry: Application in Low-Dose, Dual-Isotope Tracer Studies in Conjunction with ${ }^{14} \mathrm{C}$ Accelerator Mass Spectrometry,' Chemical Research in Toxicology, Volume 11, No. 10, (1998) 1217-1222. 